\title{
The Deep History of Earth's Biomass
}

\author{
Sean McMahon ${ }^{1} * \&$ John Parnell ${ }^{2}$ \\ ${ }^{1} U K$ Centre for Astrobiology, School of Physics and Astronomy \\ University of Edinburgh EH9 $3 F D, U K$ \\ ${ }^{2}$ School of Geosciences, University of Aberdeen, Aberdeen AB24 3UE, UK \\ *Corresponding email: sean.mcmahon@ed.ac.uk
}

\begin{abstract}
The subsurface "deep biosphere" represents one-tenth to one-third of Earth's total global present-day biomass. The rest is dominated by land plants, a relatively recent development in geological history. Before $\sim 400 \mathrm{Ma}$, a relatively low surface biomass with high productivity and fast turnover supplied carbon to a deep biosphere with high biomass but low productivity and slow turnover. Here, we argue that the deep biosphere outweighed the surface biosphere by about one order of magnitude for at least half of the history of life on Earth. This result offers a new perspective on the history of life on Earth with important implications for the search for life on other worlds.
\end{abstract}

Since the realization that life is widespread within the Earth's crust (e.g. Whitman et al. 1998, Heberling et al. 2010, Edwards et al. 2012), the deep biosphere has been recognized as an ancient, disparate and diverse ecosystem of global biogeochemical significance that provides analogues for habitats on Mars (Fisk \& Giovannoni 1999, Weiss et al. 2000, Michalski et al. 2013) as well as extrasolar planets (McMahon et al. 2013). However, estimates of the magnitude of the subsurface biomass on Earth have ranged widely. A highly cited estimate by Whitman et al. (1998) proposes a sub-seafloor prokaryotic biomass an order of magnitude greater than the surface prokaryotic biomass, and a sub-continental biomass intermediate between the two. Taking account of land plants, the total subsurface biomass (carbon) would be nearly half of the total global biomass (Whitman et al., 1998); other estimates vary between less than $1 \%$ and a third of the total biomass (Fry et al., 2008; Schrenk et al., 2010, Kallmeyer et al. 2012; McMahon and Parnell, 2014; Bar-On et al., 2018).

Regardless of which value for subsurface biomass is adopted, it is overwhelmingly dwarfed by 500 Pg C of land plants (Whitman et al., 1998; Polis, 1999; Saugier et al. 2001; Carvalhais et al. 2014; $1 \mathrm{Pg}=10^{15} \mathrm{~g}$ carbon); animals contain less than $2 \mathrm{Pg} \mathrm{C}$ (Smil, 2002; Jennings et al., 2008). The high plant biomass reflects colonisation of the free space above the soil, the large mass possible for a rooted sessile organism, access to abundant solar energy, and the preponderance of carbon-rich structural polymers and dead tissues in these organisms. Land plants are a young component of the biosphere, appearing in the Ordovician ( 470 Ma) but probably dominating global biomass only since the Devonian-Carboniferous ( 380-300 Ma) (Kenrick et al., 2012). 
In contrast, the deep biosphere is ancient. Its fossil record is regrettably under-explored, but dates back at least to the early Palaeoproterozoic (Bengtson et al., 2017) and possibly to the Archean (Rasmussen, 2000). The modern deep biosphere is dominated by prokaryotic phyla with evolutionary origins in the Archean, (e.g., Proteobacteria, Firmicutes, Chloroflexi, Crenarchaeota, Euryarchaeota and Thaumarcheota; Magnabosco et al., 2014, 2016; Parkes et al., 2014; Kieft, 2016; for divergence time estimates see, e.g., Battistuzzi et al., 2004; Magnabosco et al., 2018; Wolfe and Fournier, 2018) and by similarly ancient autotrophic and heterotrophic metabolic strategies, including methanogenesis and sulphur cycling (e.g., Ueno et al., 2006; Shen et al., 2009; Bontognali et al., 2012; Knoll et al., 2016).

These considerations suggest that the deep biosphere could have hosted most of Earth's biomass prior to the Devonian. To investigate this hypothesis, this contribution reviews the distribution of biomass on the modern Earth, and compares it with the interval between $2.0 \mathrm{Ga}$ and the spread of land plants about $0.4 \mathrm{Ga}$. This geologically well-documented timeframe post-dates the great oxygenation event at $2.4 \mathrm{Ga}$, and represents about half the history of life on Earth.

\section{The distribution of biomass}

We revisit the exhaustive classification of Earth's biomass given by Whitman et al. (1998) to describe Earth's biomass distribution today and in the interval from 2.0-0.4 Ga, prior to the proliferation of land plants (Figure 1).

\section{Land plant biomass}

Whitman et al. (1998), following Olson et al. (1983), estimated total modern plant biomass to be $\sim 560 \mathrm{Pg} \mathrm{C}$, including $470 \mathrm{Pg}$ in forests/woodlands and $90 \mathrm{Pg}$ in other ecosystems. More recent estimates of forest/woodland biomass range from 429 to $536 \mathrm{Pg}$ (Carvalhais et al. 2014; Saugier et al. 2001). This value can be scaled up to correct for recent deforestation (Crowther et al. 2015), yielding a total pre-human plant biomass of $~ 980 \mathrm{Pg} \mathrm{C}$. Somewhat higher values may have obtained in Earth's history (e.g., during the Carboniferous), but the negative feedback effect of increased forest fires under higher atmospheric oxygen concentrations would not allow global plant biomass to rise much further (Lenton and Watson, 2000).

\section{Soil and shallow terrestrial biomass}

Today: Soils contain an immense reservoir of organic carbon, but this is mostly non-living detritus (Trumbore, 1997). Whitman et al.'s (1998) estimated microbial biomass of $26 \mathrm{Pg}$ in modern terrestrial soils has recently been revised down to $\sim 15 \mathrm{Pg}$, including all prokaryotes and fungi at the Earth's land surface and within the metre below it (Serna-Chavez et al., 2013).

85

86

87

88

89

90

91
Pre-vegetation: From the Archean until the rise of land plants, the land surface hosted widespread microbial communities reliant on oxygenic photosynthesis for carbon fixation (Konhauser and Lalonde, 2015; Lenton and Daines, 2017). Evidence for these early terrestrial mats and soil crusts includes widely reported geochemical signatures of oxidative weathering, carbon fixation, organic acids and ligand production in palaeosols (e.g., Watanabe et al., 2000; Beukes et al., 2002; Neaman et al., 2005; Crowe et al., 2013; Lenton and Daines, 2017); fossils of terrestrial stromatolites and microbial mats (e.g., Buick, 1992; Eriksson et al., 2000; Prave, 
2002); and the rising abundance of sulphur in marine sediments from $\sim 2.5 \mathrm{Ga}$, attributed to microbial pyrite oxidation on land (Stüeken et al., 2012). It has been suggested that cryptogamic ground cover expanded significantly in the Neoproterozoic, but this is contested (Knauth and Kennedy, 2009; Lenton and Daines 2017).

Plants significantly increase the carbon content, nutrient availability and microbial activity of soil, as well as its volume. However, Serna-Chavez et al. (2013) show that soils in tropical forests (the most microbe-rich major soil biome) typically contain only $\sim 4.5 \mathrm{x}$ as much microbial biomass per volume as those in arid deserts, the most plant- and microbe-poor land-surface biome. If this sparse desert biome covered the entire ice-free land surface, microbial soil biomass would still be as high as $\sim 5 \mathrm{Pg} \mathrm{C}$. Even in deserts, however, soil microbial biomass is tightly concentrated around plants, and would be much lower without their fertilizing effects (e.g., Gallardo and Schlesinger, 1992; Wardle, 1992; Herman et al., 1995). We therefore suggest a prevegetation soil biomass range of $\sim 0.5-5 \mathrm{Pg} \mathrm{C}$.

\section{Aquatic biomass}

Today: Aquatic biomass is dominated by microscopic marine plankton and relatively low in aggregate. Whitman et al. (1998) estimated that prokaryotes in aquatic environments represent 2.2 Pg C. Buitenhuis et al. (2013) estimated a range of 2.5 to 7.0 Pg C for most marine plankton; including the autotrophic dinoflagellates and some nanophytoplankton missing from this estimate would raise the total to $\sim 3$ to $8.5 \mathrm{Pg} \mathrm{C}$ (E. Buitenhuis, personal communication).

Pre-vegetation: Aquatic biomass reflects a complicated interplay of climatic, bathymetric, biotic and biogeochemical factors. These factors include the nature of the dominant primary producers (once cyanobacteria, now eukaryotes), the supply of nutrients to the photic zone by runoff and upwelling, and the area and volume of shallow seas. It is unclear to what extent the proliferation of land plants increased the delivery of terrigenous nutrients to the oceans; vegetation inaugurated new and more pervasive processes of mineral weathering on land, but also permanently reduced atmospheric $\mathrm{CO}_{2}$ (suppressing weathering) and increased the retention of fines in terrestrial settings (Algeo et al., 1995; McMahon \& Davies, 2018). Nevertheless, the fossil record hints at a gradual increase in marine productivity through the Phanerozoic (e.g., Bambach, 1993; Martin et al., 1996; Falkowski et al., 2004). Primary productivity would have been favoured by higher $\mathrm{CO}_{2}$ before the Devonian, but suppressed during periods of ocean stratification and redox-controlled phosphorus limitation during the Proterozoic (e.g., Reinhard et al., 2017). Autotrophic aquatic biomass may have been smaller before eukaryotic phytoplankton rose to dominance (Falkoswki et al., 2004), and heterotrophic aquatic biomass (today twice as large as autotrophic biomass) would have been much smaller prior to the stepwise oxygenation of the oceans and the rise of metazoans through the Phanerozoic (e.g., Bambach, 1993; Martin et al., 1996). In the absence of better constraints, we suggest that the sum of modern prokaryotic aquatic biomass represents a reasonable first order estimate of total aquatic biomass in the interval from 2.0 to $0.4 \mathrm{Ga}$; i.e., about $1.5-3.5 \mathrm{Pg} \mathrm{C}$ (Buitenhuis et al., 2013).

\section{Subseafloor biomass}

Today: This reservoir encompasses biomass in sediments and rocks beneath the seafloor.

Kallmeyer et al. (2012) show on the basis of a large data set that marine sediments support a 
biomass in the range of 1.5 to $22 \mathrm{Pg} \mathrm{C}$ (expected value $\sim 4.1 \mathrm{Pg} \mathrm{C}$ ), much less than the $303 \mathrm{Pg} \mathrm{C}$ proposed by Whitman et al. (1998). This dramatic downsizing was upheld by the meta-analysis of Bar-on et al., (2018), which yielded an expected value of $\sim 7 \mathrm{Pg} \mathrm{C}$. This biomass is sustained chiefly by heterotrophy, as shown by the fact that cell counts in marine sediments are much higher at continental margins than under the open ocean where very little carbon is buried (Kallmeyer et al., 2012). In contrast, the underlying basaltic/gabbroic basement of the oceanic crust appears to be a significant habitat for chemoautotrophs fuelled by water-rock reactions (Orcutt et al., 2011). Heberling et al. (2010) estimated that this largely unexplored region could support a biomass of $200 \mathrm{Pg}$, chiefly in pillow basalt. However, the few cell counts thus far reported from oceanic basement are much lower than this model would predict, including those measured close to mid-ocean ridges where hydrothermal circulation should create favourable conditions for life (e.g., Mason et al., 2010; Salas et al., 2015 ). The available cell counts have recently been extrapolated to a biomass of oceanic basement in the range 0.5-5.0 Pg C (Bar-On et al., 2018). Total subseafloor biomass today is therefore likely to be close to $10 \mathrm{Pg} \mathrm{C}$.

Pre-vegetation: Despite secular continental growth, the volume of the subseafloor habitat has been relatively stable through the last $2 \mathrm{Ga}$ (Heberling et al. (2010). The productivity of the sediment-hosted biome is controlled by the burial of organic carbon, most of which derives from marine plankton rather than terrestrial plants. Export productivity may have increased through geological time (e.g., Bambach, 1993; Martin et al., 1996), but productivity is not the sole determinant of carbon burial, and organic-rich shales are common even in the Archean and early Proterozoic (Condie et al. 2001; Lyons et al., 2014 ). Indeed, persistent oceanic anoxia until the middle Palaeozoic facilitated copious carbon burial and could at times have supported higher subseafloor biomass than today, especially when shallow seas were more widespread.

Where carbon is plentiful, suitable electron acceptors such as sulphate and nitrate are limiting instead. Subseafloor biomass must have grown both in the basement and the sediment cover as oxidants became increasingly available beneath the oceans - a secular change that began in the Archean and accelerated with the rise of land plants (e.g., Wallace et al., 2017; Stolper \& Keller, 2018). The magnitude and rate of the growth in biomass accompanying this gradual shift in redox conditions is difficult to estimate. Energy limitation thresholds are very low in the metabolically ultra-slow deep biosphere (Hoehler \& Jørgensen, 2013), methanogens would probably have thrived beneath the low-sulphate Proterozoic oceans (e.g., Habicht et al., 2002; Crowe et al., 2011), and there is plausible fossil evidence of a deep marine biosphere as early as $2.4 \mathrm{Ga}$ (Bengtson et al., 2017). Reconstructing deep subseafloor biomass through deep time is a formidable challenge, but a conservative representative value for $\sim 2.0-0.4 \mathrm{Ga}$ would be in the range $5-10 \mathrm{Pg} \mathrm{C}$.

\section{Continental deep biomass}

Today: In contrast to the downsizing of subseafloor biomass, new cell count data from the past two decades have broadly maintained Whitman et al.'s (1998) estimate of deep continental biomass in the range of 22-215 Pg C. McMahon and Parnell (2014) derived a range of 14 to 135 $\mathrm{Pg}$ from these new data, but taking account of more recent groundwater distribution models (Gleeson et al., 2016) would raise this range to within 10\% of Whitman et al.'s original estimate. The order-of-magnitude uncertainty remaining stems from the difficulty of scaling up from unattached cell numbers measured in water to total cell numbers that include a majority adhering 
to mineral surfaces. However, independent estimates based on pore occupancy models and cell counts from bulk rock/sediment yield ranges of similar magnitude (Whitman et al., 1998; Onstott et al., 1998).

Pre-vegetation: Whereas photosynthetic organic carbon supply appears to exert an overwhelming influence on cell counts in marine sediments, no such single overriding factor has been identified in the continental crust, which sustains a higher microbial population density (Kallmeyer et al., 2012; McMahon and Parnell, 2014). The factors limiting continental deep biomass are highly localised, and include photosynthetic carbon supply, electron donors, electron acceptors, and physical conditions, notably temperature (e.g., Moser et al., 2005; Onstott et al. 2014); the relative importance of these factors in shaping the total biomass remains unclear.

Carbon limitation was probably more widespread prior to the rise of land plants; cryptogamic ground cover contributes only around $\sim 4 \%$ of terrestrial net primary production today (Elbert $e t$ $a l ., 2012)$. However, these communities are highly photosynthetically active; a cm-thick microbial mat can be as productive as a water column tens to hundreds of metres deep (Lalonde and Konhauser, 2015). Moreover, prior to the spread of land plants, these communities would have occupied a much larger proportion of Earth's surface and fixed carbon at a higher rate under the higher atmospheric $\mathrm{CO}_{2}$ concentrations then prevailing (e.g., Rothschild and Mancinelli, 1990). Microbial mats may also have exported carbon more efficiently to groundwater prior to the development of thick, extensively grazed, organic-rich soil layers, which recycle and respire carbon. Abiotic hydrocarbons, $\mathrm{CO}_{2}$ and $\mathrm{CH}_{4}$ would have provided an additional, independent carbon source for the deep biosphere, just as they do today (e.g., Chapelle et al., 2002; Sherwood Lollar, 2007). Molecular hydrogen is also widely available as an alternative electron donor in continental crust (Chapelle et al., 2002; Lin et al., 2005; Sherwood Lollar et al., 2007) and has been generated by radiolysis, serpentinization, and other processes throughout Earth history. Electron acceptors derived from photosynthetic oxygen pervaded the continental subsurface much earlier than the marine subsurface; the sulphate flux from oxidative pyrite weathering was comparable to modern values by $2.0 \mathrm{Ga}$ (Stüeken et al., 2012).

Variation in physical conditions such as crustal thickness, geothermal gradients, and porositydepth relationships may also have mediated continental biomass through deep time. The balance between sedimentary rocks and crystalline basement in the composition of the continents is especially pertinent, since sedimentary rocks are more porous; today they host $\sim 15 \times$ more groundwater - and correspondingly more biomass - than crystalline rocks (Gleeson et al., 2016). Through the Phanerozoic the proportion of basement covered by sedimentary rock fluctuated by a factor of $\sim 2$ (Ronov 1980). Erosion which led to the global unconformity at the PrecambrianCambrian boundary left a paucity of sediment at that time, and has removed much of the Proterozoic record (Peters \& Husson 2017). Nevertheless the record of shallow marine sedimentation was constant through the Proterozoic (Peters \& Husson 2017) and there is no reason to think that continental composition or total volume in the Proterozoic was systematically different from the Phanerozoic. Taken together, these considerations strongly suggest that the terrestrial subsurface biomass has been, conservatively, at least $10 \%$ its current size for $\sim 2$ billion years, i.e., at least $2-20 \mathrm{Pg} \mathrm{C}$.

\section{$\underline{\text { Discussion }}$}




\section{Table 1.}

Continental subsurface

Subseafloor Aquatic Soil Plants

Biomass, $\mathrm{Pg} \mathrm{C}$

\begin{tabular}{llllll} 
With plants (pre-human) & $20-200^{\mathrm{a}, \mathrm{b}, \mathrm{c}}$ & $10^{\mathrm{c}, \mathrm{d}}$ & $3-8.5^{\mathrm{e}}$ & $15^{\dagger}$ & $980^{\mathrm{g}, \mathrm{h,i},}$ \\
Before plants $(<2.0 \mathrm{Ga})$ & $2-20^{*}$ & $5-10$ & $1.5-3.5$ & $0.5-5$ & 0 \\
\hline
\end{tabular}

*Conservative lower limit (10\% of modern)
(a) Whitman et al., 1998
(b) McMahon \& Parnell, 2014
(c) Bar-On et al., 2018
(d) Kallmeyer et al., 2012
(e) Buitenhuis et al., 2013
(f) Serna-Chavez et al., 2013
(g) Saugier et al., 2001
(h) Carvalhais et al., 2014
(i) Crowther et al., 2015

Table 1. Illustrative values and approximate ranges of biomass carbon in different reservoirs. Modern (pre-human) values are used for the post-vegetation interval. The pre-vegetation values were estimated by the present study, as explained in the text.

The estimates discussed in the previous section are summarized in Table 1. Despite poor constraints on the estimated values of individual biomass reservoirs, it is difficult to avoid the conclusion that subsurface environments hosted the majority of Earth's biomass from 2.0 to 0.4 Ga. Even if the continental deep biosphere was as little as $10 \%$ of its present size (as in Table 1 and Figure 1), the ranges and representative values we derive indicate a deep biosphere carbon reservoir $\sim 1-15 \times$ as large as the remaining "surface biosphere" during this interval. Only after the rise of land plants did the biosphere become top-heavy, dominated by eukaryotes, and close to its present size.

Although much of the deep biosphere derives carbon from photosynthesis at the surface, this relationship does not require high surface biomass, only high surface productivity. Marine phytoplankton may account for about half of all primary productivity but contribute less than $1 \%$ of global biomass (Falkowski et al., 2004). Similarly, microbial mats and lithic crusts maintain a low standing biomass but rapidly turn over carbon (Lalonde and Konhauser, 2015). Thus, like modern oceans, the ancient continents were probably characterised by high-productivity, lowbiomass surface populations and low-productivity, high-biomass deep populations with long carbon residence times.

The extensive evidence for a subsurface biosphere on Earth has raised the possibility that other planets may also support life in a subsurface biosphere (Sherwood Lollar et al., 2007, Edwards et $a l ., 2012)$. Given that plants proliferated so recently and are expected to die out with declining $\mathrm{CO}_{2}$ less than $1 \mathrm{Ga}$ from now (O'Malley James et al., 2013), the evidence summarised here suggests that a smaller biosphere dominated by subsurface life could be considered more typical for even the most "Earth-like" inhabited terrestrial planets than the status quo on Earth itself. In fact, the hydrogen-generating mechanisms that occur in the Earth's crust should all occur on any rocky planet. The constraints of surface water, surface irradiation spectrum and surface temperature used to characterize planetary habitability do not apply to a subsurface biosphere. 
Therefore, the number of habitable planets around other stars may be substantially greater than is commonly supposed on the basis of surface habitability (McMahon et al., 2013). Despite the limits of restricted space, there are diverse eukaryotes in the terrestrial deep biosphere, including fungi, nematodes and protists (Ekendahl et al., 2003; Borgonie et al., 2011). Clearly, energy and nutrient availability in the subsurface are sufficient to support complex multicellular life. If life can originate in the subsurface, as implied by some models of abiogenesis (Sleep and Bird, 2007; Martin et al., 2008), a large proportion of life-bearing planets may be inhabited only in the subsurface. Whether such biospheres can ever be detected remains to be seen.

\section{Acknowledgements}

This paper was improved by the comments and suggestions of Graham Shields-Zhou and two anonymous reviewers. We thank E. Buitenhuis for sharing insights into aquatic biomass. S.M. acknowledges support from the European Union's Horizon 2020 Research and Innovation Programme under Marie Skłodowska-Curie grant agreement 747877.

\section{References}

1. Algeo, T.J., Berner, R.A., Maynard, J.B. and Scheckler, S.E., 1995. Late Devonian oceanic anoxic events and biotic crises:"rooted" in the evolution of vascular land plants. GSA Today, v. 5, p. 45-66.

2. Amend, J.P. \& Teske, A., 2005. Expanding frontiers in deep subsurface microbiology: Palaeogeography, Palaeoclimatology, Palaeoecology, v. 219, p. 131-155.

3. Bambach, R.K., 1993. Seafood through time: changes in biomass, energetics, and productivity in the marine ecosystem. Paleobiology, v. 19, p. 372-397.

4. Bar-On, Y.M., Phillips, R., \& Milo, R., 2018. The biomass distribution on Earth. Proceedings of the National Academy of Sciences, online view: https://doi.org/10.1073/pnas.1711842115.

5. Battistuzzi, F.U., Feijao, A. \& Hedges, S.B., 2004. A genomic timescale of prokaryote evolution: insights into the origin of methanogenesis, phototrophy, and the colonization of land. BMC Evolutionary Biology, v. 4, p. 44.

6. Bengtson, S., Rasmussen, B., Ivarsson, M., Muhling, J., Broman, C., Marone, F., Stampanoni, M. and Bekker, A., 2017. Fungus-like mycelial fossils in 2.4-billion-yearold vesicular basalt. Nature Ecology \& Evolution, v. 1, 0141.

7. Beukes, N.J., Dorland, H., Gutzmer, J., Nedachi, M., \& Ohmoto, H., 2002. Tropical laterites, life on land, and the history of atmospheric oxygen in the Paleoproterozoic. Geology, v. 30, p. 491-494.

8. Bontognali, T. R. R., Sessions, A. L., Allwood, A. C., Fischer, W. W., Grotzinger, J. P., Summons, R. E., \& Eiler, J. M., 2012. Sulfur isotopes of organic matter preserved in 
3.45-billion-year-old stromatolites reveal microbial metabolism. Proceedings of the National Academy of Sciences, v. 109, p. 15146-15151.

9. Borgonie, G., García-Moyano, A., Litthauer, D., Bert, W., Bester, A., van Heerden, E., Möller, C., Erasmus, M. \& Onstott, T.C., 2011.Nematoda from the terrestrial deep subsurface of South Africa. Nature, v. 474, p. 79-82.

10. Buick, R., 1992. The antiquity of oxygenic photosynthesis: Evidence from stromatolites in sulphate-deficient Archean lakes. Science, v. 255, p. 74-77.

11. Buitenhuis, E.T., Vogt, M., Moriarty, R., Bednaršek, N., Doney, S.C., Leblanc, K., Le Quére, C., Luo, Y.W., O’Brien, C., O’Brien, T., Peloquin, J., Schiebel, R. \& Swan, C. 2013. MAREDAT: towards a world atlas of MARine Ecosystem DATa. Earth System Science Data, v. 5, p. 227-239.

12. Carvalhais, N. et al. 2014. Global covariation of carbon turnover times with climate in terrestrial ecosystems. Nature, v. 514, p. 213-217.

13. Cawood, P.A., Hawkesworth, C.J. \& Dhuime, B. 2013. The continental record and the generation of continental crust. Geological Society of America Bulletin, 125, 14-32.

14. Chapelle, F.H., O’Neill, K., Bradley, P.M., Methé, B.A., Ciufo, S.A., Knobel, L.L. \& Lovley, D.R., 2002. A hydrogen-based subsurface microbial community dominated by methanogens.Nature, v. 415, p. 312-315.

15. Condie K.C., Des Marais, D.J. \& Abbott, D. 2001. Precambrian superplumes and supercontinents: a record in black shales, carbon isotopes, and paleoclimates? Precambrian Research, 106, 239-260.

16. Crowe, S.A., Dossing, L.N., Beukes, N.J., Bau, M., Kruger, S.J., Frei, R., \& Canfield, D.E., 2013. Atmospheric oxygenation three billion years ago. Nature, v. 501, p. 535-538.

17. Crowther, T.W. et al. 2015. Mapping tree density at a global scale. Nature, v. 525, p. 201-205.

18. D'Hondt, S. et al. 2015. Presence of oxygen and aerobic communities from sea floor to basement in deep-sea sediments. Nature Geoscience, v. 8, p. 299-303.

19. Druffel, E.R.M., Williams, P.M., Bauer, J.E. \& Ertel, J.R., 1992. Cycling of dissolved and particulate organic-matter in the open ocean. Journal of Geophysical Research, v. 97, p. $15639-15659$.

20. Dubessy, J., Pagel, M., Beny, J.-M., Christensen, H., Hickel, B., Kosztolanyi, C. \& Poty, B., 1988. Radiolysis evidenced by H2-O2 and H2-bearing fluid inclusions in three uranium deposits.Geochimica et Cosmochimica Acta, v. 52, p. 1155-1167.

21. Elbert, W., Weber, B., Burrows, S., Steinkamp, J., Büdel, B., Andreae, M.O. \& Pöschl, U. 2012. Contribution of cryptogamic covers to the global cycles of carbon and nitrogen. Nature Geoscience, 5, 459-462. 
22. Edwards, K.J., Becker, K. \& Colwell, F., 2012. The deep, dark energy biosphere: Intraterrestrial life on Earth.Annual Reviews of Earth and Planetary Sciences, v. 40, p. 551-568.

23. Ekendahl, S., O'Neill, A.H., Thomsson, E. \& Pedersen, K., 2003. Characterisation of yeasts isolated from deep igneous rock aquifers of the Fennoscandian Shield. Microbial Ecology, v. 46, p. 416-428.

24. Eriksson, P.G., Simpson, E.L., Eriksson, K.A., Bumby, A.J., Steyn, G.L., \& Sarkar, S., 2000. Muddy roll-up structures in siliciclastic interdune beds of the $c .1 .8 \mathrm{Ga}$ Waterberg Group, South Africa, Palaios, v. 15, p. 177-183.

25. Falkowski, P.G., Katz, M.E., Knoll, A.H., Quigg, A., Raven, J.A., Schofield, O. \& Taylor, F.J.R., 2004. The evolution of modern eukaryotic phytoplankton. Science, v. 305, p. 354-360.

26. Fisk, M.R. \& Giovannoni, S.J. 1999. Sources of nutrients and energy for a deep biosphere on Mars. Journal of Geophysical Research, 104, E11805-E11815.

27. Fry, J.C., Parkes, R.J., Cragg, B.A., Weightman, A.J. \& Webster, G., 2008. Prokaryotic biodiversity and activity in the deep subseafloor biosphere. FEMS Microbial Ecology, v. 66, p. 181-196.

28. Gallardo, A. and Schlesinger, W.H., 1992. Carbon \& nitrogen limitations of soil microbial biomass in desert ecosystems. Biogeochemistry, v. 18, p. 1-17.

29. Garcia-Pichel, F., Belnap, J., Neuer, S. \& Schanz, F., 2003. Estimates of global cyanobacterial biomass and its distribution. Algological Studies, v. 109, p. 213-227.

30. Gleeson, T., Befus, K.M., Jasechko, S., Luijendijk, E. \& Cardenas, M.B., 2016. The global volume and distribution of modern groundwater. Nature Geoscience, v. 9, p. 161167.

31. Hayes, J.M. \& Waldbauer, J.R., 2006. The carbon cycle and associated redox processes through time. Philosophical Transactions of the Royal Society, B, v. 361, p. 931-950.

32. Heberling, C., Lowell, R.P., Liu, L. \& Fisk, M.R., 2010. Extent of the microbial biosphere in the oceanic crust. Geochemistry Geophysics Geosystems, v. 11, doi:10.1029/2009GC002968.

33. Herman, R.P., Provencio, K.R., Herrera-Matos, J. \& Torrez, R.J., 1995. Resource islands predict the distribution of heterotrophic bacteria in Chihuahuan Desert soils. Applied and Environmental Microbiology, v. 61, p. 1816-1821.

34. Jennings, S., Mélin, F., Blanchard, J.L., Forster, R.M., Dulvy, N.K. \& Wilson, R.W., 2008. Global-scale predictions of community and ecosystem properties from simple ecological theory: Proceedings of the Royal Society B, v. 275, p. 1375-1383. 
35. Kallmeyer, J., Pockalny, R., Adhikari, R.R., Smith, D.C. \& D’Hondt, S., 2012. Global distribution of microbial abundance and biomass in subseafloor sediment. Proceedings of the National Academy of Sciences, v. 109, p. 16213-16216.

36. Kasting, J.F. \& Siefert, J.L., 2002. Life and the evolution of Earth's atmosphere. Science, v. 296, p. 1066-1068.

37. Kieft T.L., 2016. Microbiology of the Deep Continental Biosphere. In: Hurst C. (eds) Their World: A Diversity of Microbial Environments. Advances in Environmental Microbiology, v. 1. Springer, Cham.

38. Kenrick, P., Wellman, C.H., Schneider, H., \& Edgecombe, G.D., 2012. A timeline for terrestrialization: consequences for the carbon cycle in the Palaeozoic. Philosophical Transactions of the Royal Society B, v. 367, p. 519-536.

39. Knauth, L.P. \& Kennedy, M.J. 2009. The late Precambrian greening of the Earth. Nature, v. 460 , p. $728-732$.

40. Knoll, A.H., Bergmann, K.D. \& Strauss, J.V., 2016. Life: the first two billion years. Phil. Trans. R. Soc. B, v. 371, p. 20150493.

41. Lalonde, S.V. and Konhauser, K.O., 2015. Benthic perspective on Earth's oldest evidence for oxygenic photosynthesis. Proceedings of the National Academy of Sciences, v. 112, p. 995-1000.

42. Lenton, T.M. \& Daines, S.J., 2017. Matworld-the biogeochemical effects of early life on land. New Phytologist, v. 215, p. 531-537.

43. Lenton, T.M. \& Watson, A.J., 2000. Redfield revisited 2. What regulates the oxygen content of the atmosphere? Global Biogeochemical Cycles, v. 14, p. 249-268.

44. Lin, L.H., Hall, J., Lippmann-Pipke, J., Ward, J.A., Sherwood Lollar, B., DeFlaun, M., Rothmel, R., Moser, D., Gihring, T.M., Mislowack, B. \& Onstott, T.C., 2005. Radiolytic $\mathrm{H}_{2}$ in continental crust. Nuclear power for deep subsurface microbial communities; Geochemistry, Geophysics, Geosystems, v. 6, Q07003, doi:10.1029/2004GC000907.

45. Lipp, J.S., Morono, Y., Inagaki, F. \& Hinrichs, K. U. 2008. Significant contribution of Archaea to extant biomass in marine subsurface sediments. Nature, v. 454, p. 991-994.

46. Lyons, T.W., Reinhard, C.T. \& Planavsky, N.J., 2014. The rise of oxygen in Earth's early ocean and atmosphere. Nature, v. 506, p. 307-315.

47. Magnabosco, C., Moore, K.R., Wolfe, J.M. \& Fournier, G.P., 2018. Dating phototrophic microbial lineages with reticulate gene histories. Geobiology, v. 16, p.179-189.

48. Magnabosco, C., Ryan, K., Lau, M.C., Kuloyo, O., Lollar, B.S., Kieft, T.L., Van Heerden, E. \& Onstott, T.C., 2016. A metagenomic window into carbon metabolism at 3 km depth in Precambrian continental crust. The ISME journal, v. 10, p.730-741. 
49. Magnabosco, C., Tekere, M., Lau, M.C., Linage, B., Kuloyo, O., Erasmus, M., Cason, E., van Heerden, E., Borgonie, G., Kieft, T.L. \& Olivier, J., 2014. Comparisons of the composition and biogeographic distribution of the bacterial communities occupying South African thermal springs with those inhabiting deep subsurface fracture water. Frontiers in Microbiology, v. 5, p. 679.

50. Martin, R.E., 1996. Secular increase in nutrient levels through the Phanerozoic: implications for productivity, biomass, and diversity of the marine biosphere. Palaios, 209-219.

51. Martin, W., Baross, J., Kelley, D. \& Russell, M.J., 2008. Hydrothermal vents and the origin of life. Nature Reviews in Microbiology, v. 6, p. 805-814.

52. Mason, O.U., Nakagawa, T., Rosner, M., Van Nostrand, J.D., Zhou, J., Maruyama, A., Fisk, M.R. \& Giovannoni, S.J., 2010. First investigation of the microbiology of the deepest layer of ocean crust. PLoS one, 5, p.e15399.

53. McMahon, S., O’Malley-James, J. \& Parnell, J., 2013. Circumstellar habitable zones for deep terrestrial biospheres. Planetary and Space Science, v. 85, p. 312-318.

54. McMahon, S. \& Parnell, J., 2014. Weighing the deep continental biosphere. FEMS Microbiology Ecology, v. 87, p. 113-120.

55. McMahon, W.J. \& Davies, N.S., 2018. Evolution of alluvial mudrock forced by early land plants. Science, v. 359, p.1022-1024.

56. Michalski, J.R., Cuadros, J., Niles, P.B., Parnell, J., Rogers, A.D. \& Wright, S.P. 2013. Groundwater activity on Mars and implications for a deep biosphere. Nature Geoscience, v. 6, p. 133-138.

57. Neaman, A., Chorover, J., Brantley, S.L., 2005. Element mobility patterns record organic ligands in soils on early Earth. Geology, v. 33, p. 117-120.

58. Olson, J.S., Watts, J.A. \& Allison, L.J. 1983. Carbon in live vegetation of major world ecosystems. Oak Ridge National Laboratory Environmental Sciences Division Publication No. 1997. Washington D.C., U.S. Department of Energy.

59. O'Malley-James, J.T., Greaves, J.S., Raven, J.A. and Cockell, C.S., 2013. Swansong biospheres: refuges for life and novel microbial biospheres on terrestrial planets near the end of their habitable lifetimes. International Journal of Astrobiology, 12), pp.99-112.

60. Onstott, T.C., Phelps, T.J., Kieft, T., Colwell, F.S., Balkwill, D.L., Fredrickson, J.K., \& Brockman, F.J. 1999. in: Enigmatic Microorganisms and Life in Extreme Environments (ed. J. Seckbach) p. 489-499. Kluwer, 1999.

61. Onstott, T.C., Magnabosco, C., Aubrey, A.D., Burton, A.S., Dworkin, J.P., Elsila, J.E., Grunsfeld, S., Cao, B.H., Hein, J.E., Glavin, D.P. and Kieft, T.L., 2014. Does aspartic acid racemization constrain the depth limit of the subsurface biosphere?. Geobiology, v. 12, p.1-19. 
62. Orcutt, B.N., Sylvan, J.B., Knab, N.J. \& Edwards, K.J., 2011. Microbial ecology of the dark ocean above, at, and below the seafloor. Microbiology and Molecular Biology Reviews, 75, 361-422.

63. Orsi, W.D., Edgcomb, V.P., Christman, G.D. \& Biddle, J.F. 2013. Gene expression in the deep biosphere. Nature, v. 499, p. 205-208.

64. Parkes, R.J., Cragg, B., Roussel, E., Webster, G., Weightman, A. \& Sass, H., 2014. A review of prokaryotic populations and processes in sub-seafloor sediments, including biosphere: geosphere interactions. Marine Geology, v. 352, p. 409-425.

65. Parnell, J., Boyce, A.J. \& Blamey, N.J.F., 2010. Follow the methane: the search for a deep biosphere, and the case for sampling serpentinites, on Mars. International Journal of Astrobiology, v. 9, p. 193-200.

66. Pedersen, T.F. \& Calvert, S.E. 1990. Anoxia vs. productivity: what controls the formation of organic-carbon-rich sediments and sedimentary rocks? AAPG Bulletin, v. 74, p. 454466.

67. Peters, S.E. \& Husson, J.M. 2017. Sediment cycling on continental and oceanic crust. Geology, doi:10.1130/G38861.1

68. Pinto, J.P. \& Holland, H.D., 1988. Paleosols and the evolution of the atmosphere; Part II. Geological Society of America Special Paper v. 216, p. 21-34.

69. Polis, G.A. 1999. Why are parts of the world green? Multiple factors control productivity and the distribution of biomass. Oikos, v. 86, p. 3-15.

70. Prave, A.R., 2002. Life on land in the Proterozoic: evidence from the Torridonian rocks of northwest Scotland. Geology, v. 30, p. 811-814.

71. Rasmussen, B., 2000. Filamentous microfossils in a 3,235-million-year-old volcanogenic massive sulphide deposit. Nature, v. 405, p. 676-679.

72. Reinhard, C.T., Planavsky, N.J., Gill, B.C., Ozaki, K., Robbins, L.J., Lyons, T.W., Fischer, W.W., Wang, C., Cole, D.B. and Konhauser, K.O., 2017. Evolution of the global phosphorus cycle. Nature, v. 541, p. 386-389.

73. Riding, R., 2006. Microbial carbonate abundance compared with fluctuations in metazoan diversity over geological time.Sedimentary Geology, v. 185, p. 229-238.

74. Ronov, A.B., Khain, V.E., Balukhovsky, A.N. \& Seslavinsky, K.B. 1980. Quantitative analysis of Phanerozoic sedimentation. Sedimentary Geology, v. 25, p. 311-325.

75. Rosing, M.T. \& Frei, R., 2004. U-rich Archaean sea-floor sediments from Greenland indications of $>3700 \mathrm{Ma}$ oxygenic photosynthesis. Earth and Planetary Science Letters, v. 217 , p. $237-244$.

76. Rothschild, L.J. \& Mancinelli, R.L., 1990. Model of carbon fixation in microbial mats from 3,500 Myr ago to the present. Nature, v. 345, p. 710-712. 
77. Salas, E.C., Bhartia, R., Anderson, L., Hug, W.F., Reid, R.D., Iturrino, G. \& Edwards, K.J., 2015. In situ detection of microbial life in the deep biosphere in igneous ocean crust. Frontiers in microbiology, v. 6, p.1260.

78. Saltzman, M.R., 2005. Phosphorus, nitrogen, and the redox evolution of the Paleozoic oceans. Geology, v. 33, p. 573-576.

79. Saugier, B., Roy, J. \& Mooney, H.A. 2001. Estimations of global terrestrial productivity: Converging toward a single number? In; Roy, J., Saugier, B. \& Mooney, H.A. (eds) Terrestrial Global Productivity. Academic Press, New York, 543-557.

80. Schrenk, M.O., Huber, J.A. \& Edwards, K.J., 2010. Microbial provinces in the subseafloor. Annual Reviews of Marine Science, v. 2, p. 279-304.

81. Serna-Chavez, H.M., Fierer, N. \& van Bodegom, P.M. 2013. Global drivers and patterns of microbial abundance in soil. Global Ecology and Biogeography, 22, 1162-1172.

82. Shen, Y., Farquhar, J., Masterson, A., Kaufman, A. J., \& Buick, R., 2009. Evaluating the role of microbial sulfate reduction in the early Archean using quadruple isotope systematics. Earth and Planetary Science Letters, v. 279, p. 383-391.

83. Sherwood Lollar, B., Voglesonger, K., Lin, L.-H., Lacrampe-Couloume, G., Telling, J., Abrajano, T.A., Onstott, T.C. \& Pratt, L.M., 2007. Hydrogeologic controls on episodic $\mathrm{H}_{2}$ release from Precambrian fractured rocks - energy for deep subsurface life on Earth and Mars.Astrobiology, v. 7, p. 971-986.

84. Sleep, N.H. \& Bird, D.K., 2007. Niches of the pre-photosynthetic biosphere and geologic preservation of Earth's earliest ecology. Geobiology, v. 5, p. 101-117.

85. Smil, V., 2003. The Earth's biosphere: Evolution, dynamics, and change. MIT Press.

86. Stolper, D.A. and Keller, C.B., 2018. A record of deep-ocean dissolved O 2 from the oxidation state of iron in submarine basalts. Nature, 553, 323-327.

87. Stüeken, E.E., Catling, D.C. \& Buick, R., 2012. Contributions to late Archaean sulphur cycling by life on land. Nature Geoscience, v. 5, p. 459-462.

88. Trumbore, S.E., 1997. Potential responses of soil organic carbon to global environmental change. Proceedings of the National Academy of Sciences, v. 94, 8284-8291.

89. Ueno, Y., Yamada, K., Yoshida, N., Maruyama, S., \& Isozaki, Y., 2006. Evidence from fluid inclusions for microbial methanogenesis in the early Archaean era. Nature, v. 440, p. $516-519$.

90. Wallace, M.W., Shuster, A., Greig, A., Planavsky, N.J. \& Reed, C.P., 2017. Oxygenation history of the Neoproterozoic to early Phanerozoic and the rise of land plants. Earth and Planetary Science Letters, 466, 12-19. 
91. Wardle, D.A., 1992. A comparative assessment of factors which influence microbial biomass carbon and nitrogen levels in soil. Biological reviews, v. 67, p. 321-358.

92. Watanabe, Y., Martini, J.E. \& Ohmoto, H., 2000. Geochemical evidence for terrestrial ecosystems 2.6 billion years ago. Nature, v. 408, p. 574-578.

93. Weiss, B.P., Yung, Y.L. \& Nealson, K.H. 2000. Atmospheric energy for subsurface life on Mars? Proceedings National Academy of Sciences, 97, 1395-1399.

94. Whitman, W.B., Coleman, D.C. \& Wiebe, W.J., 1998. Prokaryotes: The unseen majority: Proceedings of the National Academy of Sciences USA, v. 95, p. 6578-6583.

95. Wolfe, J.M. and Fournier, G.P., 2018. Horizontal gene transfer constrains the timing of methanogen evolution. Nature Ecology \& Evolution, v. 2, p. 897.

\section{Figure 1}

(a)

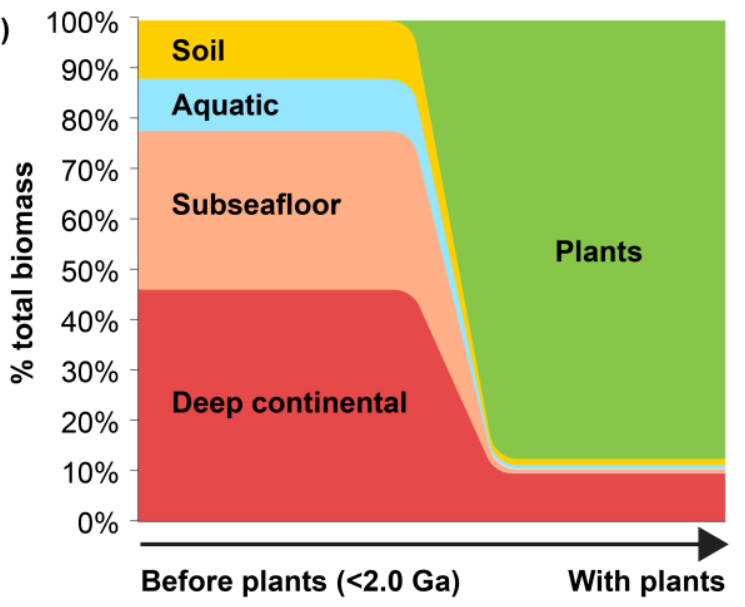

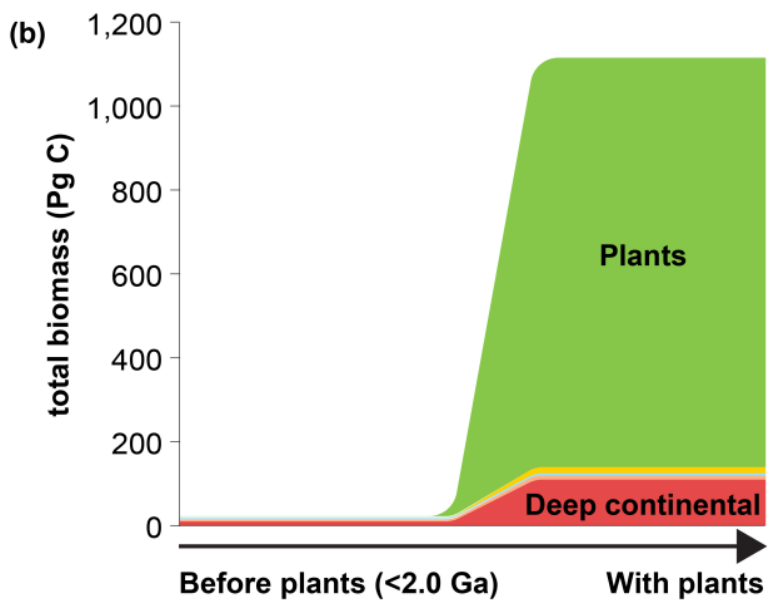

Figure 1. Earth's biomass carbon in different reservoirs pre- and post-vegetation, based on the values (and mid-values of ranges) shown in Table 1, (a) as percentages of the total, and (b) as absolute values. 